\title{
Erratum to: Reward functions of the basal ganglia
}

\author{
Wolfram Schultz ${ }^{1}$
}

Published online: 26 June 2017

(c) Springer-Verlag Wien 2017

\section{Erratum to: J Neural Transm (2016) 123:679-693 DOI 10.1007/s00702-016-1510-0}

The article "Reward functions of the basal ganglia", written by Wolfram Schultz, was originally published electronically on the publisher's internet portal (currently SpringerLink) on 02 February 2016 without open access. The original article was corrected.

With the author(s)' decision to opt for Open Choice the copyright of the article changed on June 28,2017 to (C) The Author(s) 2017 and the article is forthwith distributed under the terms of the Creative Commons Attribution 4.0 International License (http://creativecommons.org/licen ses/by/4.0/), which permits use, duplication, adaptation, distribution and reproduction in any medium or format, as long as you give appropriate credit to the original author(s) and the source, provide a link to the Creative Commons license, and indicate if changes were made.

The online version of the original article can be found under doi: 10.1007/s00702-016-1510-0.

Wolfram Schultz

ws234@cam.ac.uk

1 Department of Physiology, Development and Neuroscience, University of Cambridge, Cambridge CB2 3DY, UK 